\title{
The effect of settlement time on reducing coagulant dosage in water treatment plants
}

\author{
Safaa N. Hassan \\ Faculty of science, Environmental Engineering Department, Collage of Engineering, Al-Mustansiriya \\ University, Bab Al-Muathem P.O.Box 14150 Baghdad, Iraq
}

Rec. 12 Aug, 2011 Accpt. 19 Sep, 2011

\begin{abstract}
Turbidity is a measure of the relative clarity of water. Its removal is one of the important steps in water treatment process and it's generally achieved using coagulation/flocculation process. The most wildly coagulant used in water treatment plants is Aluminum sulfite (Alum). The aim of this study is to reduce the amount of Alum used in Iraqi water treatment plants as much as possible in order to reduce its side effects but yet stay within required quality of water requirements; this was done by testing different durations of slow mixing with Alum and finale settlement as well. This research showed that the percentage removal of turbidity increases when the time of slow mixing with Alum and the time of final settlement of the water samples were increased for the same dosage of Alum used, hence, decreasing the final turbidity of water. The dosage of Alum added to the water sample was reduced to the half and obtained the same percentage of final turbidity removal by increasing the time of slow mixing and final settlement. An empirical equation was obtained relating the percentage of removal with the Alum dosage, time of slow mixing, time of final settlement and final turbidity of water samples. Extra safety from the effect of Alum on human body is offered by reducing the amount of Alum used in water treatment plants and increasing the time of final settlement.
\end{abstract}

Key words: water, turbidity, coagulation, flocculation, jar test, coagulants, alum, slow mix time and final settlement time.

\section{Introduction}

Turbidity is one of the major problems in water treatment plant, water turbidity increases as a result of suspended solids in the water that reduces the transmission of light. Suspended solids varied, ranging from clay, silt and plankton to industrial wastes and sewage. Removing turbidity is usually done by adding a coagulant to the turbid water in the coagulation/flocculation process. This process is complex and involves dissolution, hydrolysis and polymerization (Lee et al., 2007). In most of Iraqi water treatment plants, if not all, the type of coagulant used is Aluminum sulfite (Alum) duo to its low cost, high efficiency in removing turbidit and a lot of other advantages compared with other types of coagulants. Recent studies has shown that in spite of all advantages of Alum, there are some disadvantages such as introducing
Aluminum into treated water, which may have some side effects such as Alzheimer's disease.

From the engineering point of view, application of coagulation and flocculation is necessary for removal and settlement of colloidal particles, which in the case of clay particles has a negative charge. Because of the presence of these similar charges, the colloidal particles cannot get together and form a heavier particle for settlement (Nasser et al., 1994).

This stable system should be unstabelized by the application of coagulants. In this regards, the particles will enough close to each other to make heavier and bigger particles (Metcalf and Eddy, 1982).

Many coagulants have been widely used in conventional water treatment process depending on their chemical characteristics such as Ferric chloride, Aluminum chloride and others. Several studies on using natural

\footnotetext{
Corresponding author:

Dr. Safaa N. Hassan
}

凶eng.safa74@yahoo.com 
coagulants produced or extracted from microorganisms, biochemical, animals and plants have been carried out such as pectin (Ho et al., 2008) ,Moringa oleifera (Katayon et al., 2004) and others (Mahvi et al., 2005, Ganjidoust et al., 1997; Kawamura et al., 1991; Lee et al., 1995; Qilin et al., 2005).

Because of its many advantages, comparing with other coagulants, the most widely used coagulant material in water treatment plants, especially in Iraq, is Aluminum Sulfite " $\mathrm{AL}_{2}\left(\mathrm{SO}_{4}\right)_{3} .18 \mathrm{H}_{2} \mathrm{O}$ " which is also known as Alum. Some of these advantages are that Alum coagulation provides rapid, highly efficient removal of solids, phosphorus and bacteria. Liquid alum is relatively inexpensive, resulting in low unit costs per mass of pollutant removal. Unlike other coagulants, alum dose does not deteriorate under longterm storage. Liquid alum contains substantially less heavy metal contamination than other metal coagulants. Alum floc is chemically inert and is immune to dissolution from normal fluctuation $\mathrm{PH}$.

In spite of advantages of Alum, still it has disadvantages raised by recent studies, such as advisability of introducing aluminum into the environment especially concerning about residuals into treated water and large production of sludge volume. Several researches showed the relation between aluminum and Alzheimer's disease, (the Lancet, 1989). reported that the risk of Alzheimer's disease was increased $50 \%$ in areas with high concentration of aluminum (The Lancet, 1989). Aluminum is not healthy for any life forms; it causes damages to almost all types of living tissues and has a tendency to accumulate in the brain and bones of those who ingest it (The silent enemy, 2008).

Aluminum can inhibit the body's ability to digest and make use of Calcium, Magnesium, Iron, Phosphorus and Fluoride. This can cause anemia, prevent bone growth and reduce bone density (Susan at el., 2008). The relation between concentration of Aluminum in drinking water and Alzheimer's disease was investigated by researchers and it was found that a high concentration of Aluminum in drinking water may be a risk factor for Alzheimer's disease (Virginie at el., 1999;
Pricilla at el., 2008). and Parkinsonismdementia (Hewitt at el., 1990). Cognitive decline is greater with time in subjects with a higher daily intake of Aluminum from drinking water $(>0.1 \mathrm{mg} /$ day $)$ or higher geographic exposure to Aluminum (Virginie at el., 2008).

\section{Abbreviation:}

NTU or TU: stands for Nephelometric turbidity units, a measurement of the turbidity of water; rpm: round per minute; SIU: Standard International Units; IS: Iraqi Standard.

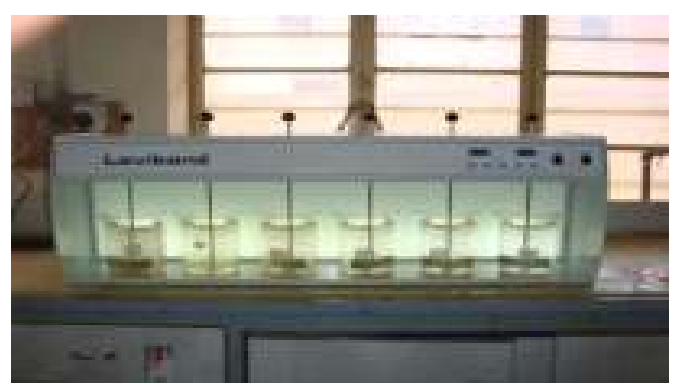

Picture (1) The jar test apparatus.

\section{Material and Method \\ Water Samples}

The water samples used in all experiments were artificial samples, made in the laboratory by wasting the same amount of certain clay in the same amount of water for each experiment and by that the same water properties are obtained including initial turbidity for each sample. This was done to simulate the river water.

\section{Experimental work}

The experimental work was conducted in the sanitary engineering laboratory, department of environmental engineering, college of engineering, Al-Mustansiriya University in Baghdad, Iraq.

Other properties of water samples were fixed such as PH, Alkalinity and water temperature in order to eliminate their effects on the results of the experiments.

Several experiments were conducted during this study in which the time of slow mixing with Alum and the time of final settlement of the water samples were investigated as well as different weights of Alum dosage. 
Each experiment was made with the following procedure:

- The initial turbidity of water is measured and established.

- Five different dosage of Alum was prepared ranging from $5 \mathrm{mg} / 1$ to $50 \mathrm{mg} / \mathrm{l}$.

- The first container of the jar test apparatus was remained without any coagulant while the other five jars were added with different dosage of Alum.

- The jar test was started with a rapid mix of $100 \mathrm{rpm}$ for one minute, and then a slow mix of $20 \mathrm{rpm}$, for different durations ranging from 10 to 40 minutes, was applied.

- Settling time was taken for different durations ranging from 35 to 80 minutes.

- After the settlement was finished the turbidity is measured for each of the six containers in the jar test.

\section{Results and Discussion}

Initial evaluation of the experimental work was carried out by simply plotting the experimental data obtained as shown in figures (1-6), each figure represents the relation between the final turbidity of the water sample with Alum dosage using different times of slow mixing and final settlement in every figure.

The six figures can be classified into two categories, each category contain three figures. The first category, figures (1-3), supplemented with an Alum dosage of 10, 20, 30, 40, and50 $\mathrm{mg} / \mathrm{l}$ as repeated in each figure. The time of slow mixing varied as follows 10,15 and 30 minutes respectively, while the times of final settlements were 35,40 and 60 minutes respectively.

The second category, figures(4-6), supplemented with an Alum dosage of 5, 10, 15,20 and $25 \mathrm{mg} / 1$ repeated for each figure while the time of slow mixing used were 15 , 30 and 40 minutes respectively. The times of final settlements were 40, 60 and 80 minutes respectively.

The results of all experiments are illustrated in table 1.

From figures (1-3), it is obvious that the final turbidity of water samples was reduced by increasing the time of slow mixing and the time of final settlement for the same dosage of
Alum used( varying from 10 to $50 \mathrm{mg} / \mathrm{l}$ ) and by that the time's effect is clear.

In figures (4-6) the dosage of Alum was decreased reaching one half its dosages used in the first three figures (from 5 to $25 \mathrm{mg} / \mathrm{l}$ ) and to obtain the same results of finale turbidity for treated water (within 5 NTU) the time of slow mixing and the time of final settlement was increased.

Figures (7 and 8) show the relation between the percentage of removal and the time of final settlement for different dosage of Alum. In figure 7 the Alum dosage was 50 $\mathrm{mg} / \mathrm{l}$ and the time of settlement varied from 35 to 60 minutes, from this figure one can see that the percentage of removal of turbidity was increased up to $97 \%$ when increasing the time of final settlement up to 60 minutes. In figure 8 the Alum dosage taken was $25 \mathrm{mg} / 1$ and the time of final settlement varied from 40 to 80 minutes, the highest percentage of turbidity removal was $94 \%$ for the longest time of settlement (80 minutes) and with half dosage of Alum used compared experiments shown in figure 7.

The ratio between the percentage removal of turbidity and the time of settlement was direct relation, whenever the time of settlement was increased the amount of percentage removal of turbidity was increased for the same dosage of Alum, which can be useful to decrease the Alum dosage used and still obtain the same results required from drinking water requirements. All of that can be illustrated in table 2 which contains the percentage removal along with the temperature, $\mathrm{PH}$, initial and final turbidity for all experiments. The data in this table indicated that the percentage of removal increases with the increase of final settlement time reaching its highest value of $97.2 \%$ in the third experiment where the dosage of Alum was $50 \mathrm{mg} / \mathrm{l}$ and the time of settlement was 60 minutes. The second highest percentage of removal was $94.3 \%$ and it was obtained when the dosage of Alum used was $25 \mathrm{mg} / \mathrm{l}$ and the time of final settlement was 80 minutes.

An empirical relation was obtained relating the percentage of removal with the Alum dosage, time of final settlement, time of slow mixing and the final turbidity of water samples. 
This equation below has a correlation coefficient (r) equal to $92.67 \%$.

Where:

$\mathrm{R} \%=$ The percentage of turbidity removal.

$\mathrm{A}_{\mathrm{L}}=$ The Alum dosage, in $\mathrm{mg} / \mathrm{l}$.

$\mathrm{T}_{\mathrm{fs}}=$ Time of final settlement, in minutes.

$\mathrm{T}_{\mathrm{sm}}=$ Time of slow mixing with Alum, in minutes.

Tur. $=$ Final turbidity of water samples, in NTU.

$\rho=$ Water density, in $\mathrm{gm} / \mathrm{cm}^{3}$.

Equation (1) indicates that the percentage of removal has a direct proportion with the dosage of Alum and the time of final settlement and an inverse proportion with the final turbidity of water sample.

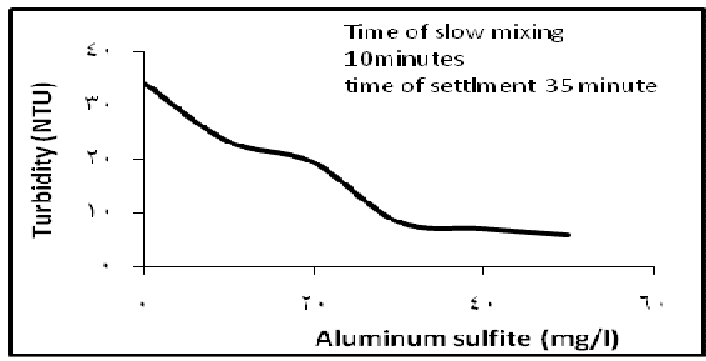

Figure. 1: The relation between Alum dosage and turbidity for test no.1

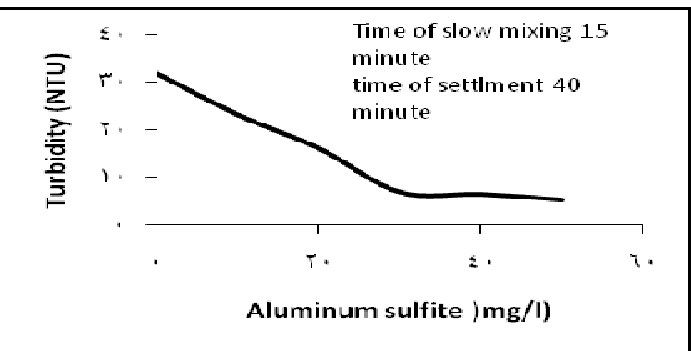

Figure. 2: The relation between Alum dosage and turbidity for test no.2

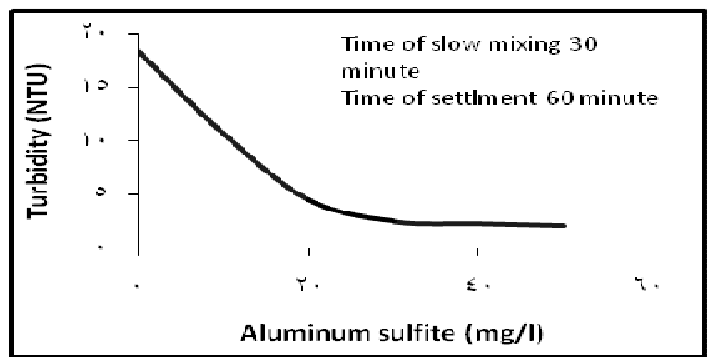

Figure. 3: The relation between Alum dosage and turbidity for test no.3

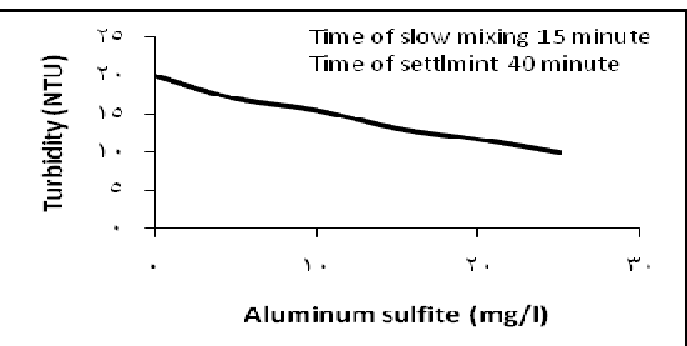

Figure. 4: The relation between Alum dosage and turbidity for test no.4

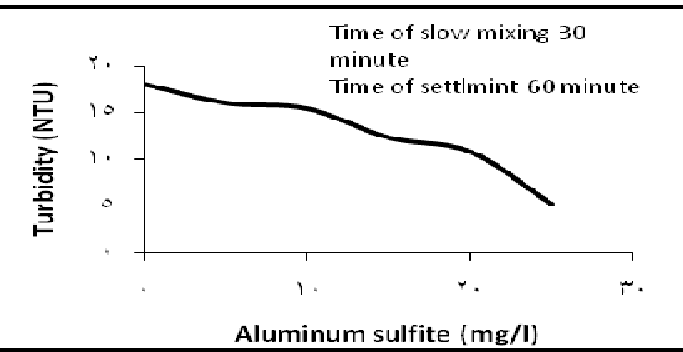

Figure. 5: The relation between Alum dosage and turbidity for test no. 5

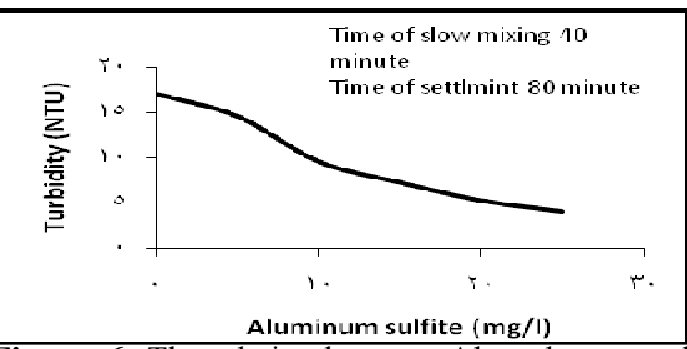

Figure. 6: The relation between Alum dosage and turbidity for test no.6

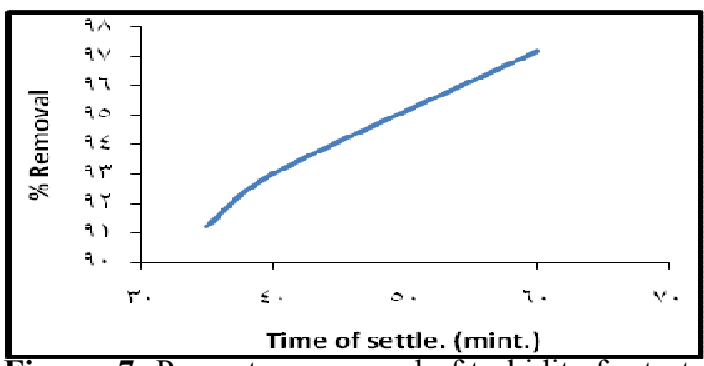

Figure. 7: Percentage removal of turbidity for tests $1-3$

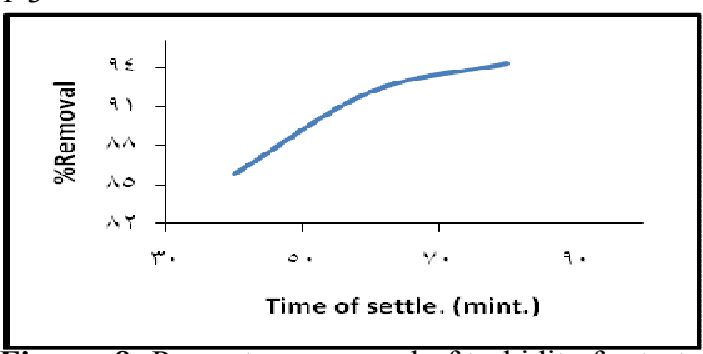

Figure. 8: Percentage removal of turbidity for tests 4-6 


\section{Conclusions}

The following conclusions have been drawn from the results of the experimental conditions of the present study:

1- The increase of the finale settling time, along with the slow mixing duration of the water sample decreases the final amount of turbidity, for the same dosage of Alum added to water sample.
2- The reduction of the Alum dosage can be done and obtain the same results required for water quality by increasing the time of finale settlement and the time of slow mixing with Alum.

3- An empirical equation was obtained relating the percentage of removal with the Alum dosage, time of final settlement, time of slow mixing and final turbidity of water samples.

\begin{tabular}{|c|c|c|c|c|}
\hline $\begin{array}{l}\text { Experiment } \\
\text { number }\end{array}$ & $\begin{array}{c}\text { Alum dosage } \\
\mathrm{mg} / \mathrm{l}\end{array}$ & $\begin{array}{c}\text { Time of slow } \\
\text { mixing, minute }\end{array}$ & $\begin{array}{c}\text { Time of final } \\
\text { settlement ,minute }\end{array}$ & $\begin{array}{c}\text { Final turbidity } \\
\text { NTU }\end{array}$ \\
\hline \multirow{6}{*}{1} & 0 & 10 & 35 & 34.5 \\
\hline & 10 & 10 & 35 & 23.4 \\
\hline & 20 & 10 & 35 & 19.5 \\
\hline & 30 & 10 & 35 & 8.3 \\
\hline & 40 & 10 & 35 & 7.0 \\
\hline & 50 & 10 & 35 & 5.9 \\
\hline \multirow{6}{*}{2} & 0 & 15 & 40 & 32 \\
\hline & 10 & 15 & 40 & 23.2 \\
\hline & 20 & 15 & 40 & 16.3 \\
\hline & 30 & 15 & 40 & 7.1 \\
\hline & 40 & 15 & 40 & 6.7 \\
\hline & 50 & 15 & 40 & 5.5 \\
\hline \multirow{6}{*}{3} & 0 & 30 & 60 & 18.4 \\
\hline & 10 & 30 & 60 & 10.7 \\
\hline & 20 & 30 & 60 & 4.5 \\
\hline & 30 & 30 & 60 & 2.5 \\
\hline & 40 & 30 & 60 & 2.3 \\
\hline & 50 & 30 & 60 & 2.1 \\
\hline \multirow{6}{*}{4} & 0 & 15 & 40 & 20 \\
\hline & 5 & 15 & 40 & 17 \\
\hline & 10 & 15 & 40 & 15.5 \\
\hline & 15 & 15 & 40 & 13.1 \\
\hline & 20 & 15 & 40 & 11.7 \\
\hline & 25 & 15 & 40 & 10 \\
\hline \multirow{6}{*}{5} & 0 & 30 & 60 & 18 \\
\hline & 5 & 30 & 60 & 16 \\
\hline & 10 & 30 & 60 & 15.4 \\
\hline & 15 & 30 & 60 & 12.3 \\
\hline & 20 & 30 & 60 & 10.8 \\
\hline & 25 & 30 & 60 & 6.2 \\
\hline \multirow{6}{*}{6} & 0 & 40 & 80 & 17 \\
\hline & 5 & 40 & 80 & 14.5 \\
\hline & 10 & 40 & 80 & 9.5 \\
\hline & 15 & 40 & 80 & 7.2 \\
\hline & 20 & 40 & 80 & 5.2 \\
\hline & 25 & 40 & 80 & 4.0 \\
\hline
\end{tabular}

Table 1. Results of all experiments 


\begin{tabular}{|c|c|c|c|c|c|c|c|}
\hline $\begin{array}{l}\text { Exp. } \\
\text { No. }\end{array}$ & $\mathbf{P H}$ & $\begin{array}{l}\text { Temp. } \\
{ }^{\circ} \mathrm{C}\end{array}$ & $\begin{array}{l}\text { Time of } \\
\text { slow } \\
\text { mix.,min }\end{array}$ & $\begin{array}{l}\text { Time of final } \\
\text { settlement, min }\end{array}$ & $\begin{array}{c}\text { Initial } \\
\text { turbidity, } \\
\text { NTU }\end{array}$ & $\begin{array}{c}\text { Final } \\
\text { turbidity, } \\
\text { NTU }\end{array}$ & $\begin{array}{c}\text { Percentage } \\
\text { of } \\
\text { removal\% }\end{array}$ \\
\hline \multirow{6}{*}{1} & 6.11 & 18 & 10 & 35 & 71.2 & 34.5 & 51.55 \\
\hline & 6.11 & 18 & 10 & 35 & 71.2 & 23.4 & 67.13 \\
\hline & 6.11 & 18 & 10 & 35 & 71.2 & 19.5 & 72.61 \\
\hline & 6.11 & 18 & 10 & 35 & 71.2 & 8.3 & 88.34 \\
\hline & 6.11 & 18 & 10 & 35 & 71.2 & 7 & 90.17 \\
\hline & 6.11 & 18 & 10 & 35 & 71.2 & 5.9 & 91.71 \\
\hline \multirow{6}{*}{2} & 6.35 & 18 & 15 & 40 & 78 & 32 & 59 \\
\hline & 6.35 & 18 & 15 & 40 & 78 & 23.2 & 70.26 \\
\hline & 6.35 & 18 & 15 & 40 & 78 & 16.3 & 79.1 \\
\hline & 6.35 & 18 & 15 & 40 & 78 & 7.1 & 90.9 \\
\hline & 6.35 & 18 & 15 & 40 & 78 & 6.7 & 91.41 \\
\hline & 6.35 & 18 & 15 & 40 & 78 & 5.5 & 92.95 \\
\hline \multirow{6}{*}{3} & 6.27 & 18 & 30 & 60 & 74 & 18.4 & 75.14 \\
\hline & 6.27 & 18 & 30 & 60 & 74 & 10.7 & 85.54 \\
\hline & 6.27 & 18 & 30 & 60 & 74 & 4.5 & 93.92 \\
\hline & 6.27 & 18 & 30 & 60 & 74 & 2.5 & 96.62 \\
\hline & 6.27 & 18 & 30 & 60 & 74 & 2.3 & 96.89 \\
\hline & 6.27 & 18 & 30 & 60 & 74 & 2.1 & 97.2 \\
\hline \multirow{6}{*}{4} & 6.19 & 18 & 15 & 40 & 70.2 & 20 & 71.51 \\
\hline & 6.19 & 18 & 15 & 40 & 70.2 & 17 & 75.78 \\
\hline & 6.19 & 18 & 15 & 40 & 70.2 & 15.5 & 77.92 \\
\hline & 6.19 & 18 & 15 & 40 & 70.2 & 13.1 & 81.34 \\
\hline & 6.19 & 18 & 15 & 40 & 70.2 & 11.7 & 83.33 \\
\hline & 6.19 & 18 & 15 & 40 & 70.2 & 10 & 85.75 \\
\hline \multirow{6}{*}{5} & 6.15 & 18 & 30 & 60 & 78.1 & 18 & 76.95 \\
\hline & 6.15 & 18 & 30 & 60 & 78.1 & 16 & 79.51 \\
\hline & 6.15 & 18 & 30 & 60 & 78.1 & 15.4 & 80.28 \\
\hline & 6.15 & 18 & 30 & 60 & 78.1 & 12.3 & 84.25 \\
\hline & 6.15 & 18 & 30 & 60 & 78.1 & 10.8 & 86.17 \\
\hline & 6.15 & 18 & 30 & 60 & 78.1 & 6.2 & 92.06 \\
\hline \multirow{6}{*}{6} & 6.25 & 18 & 40 & 80 & 70 & 17 & 75.71 \\
\hline & 6.25 & 18 & 40 & 80 & 70 & 14.5 & 79.29 \\
\hline & 6.25 & 18 & 40 & 80 & 70 & 9.5 & 86.43 \\
\hline & 6.25 & 18 & 40 & 80 & 70 & 7.2 & 89.71 \\
\hline & 6.25 & 18 & 40 & 80 & 70 & 5.2 & 92.57 \\
\hline & 6.25 & 18 & 40 & 80 & 70 & 4 & 94.3 \\
\hline
\end{tabular}

Table2. Percentage removal of turbidity 
References

Ganjidoust, H., Tatsumi K., Yamagishi, T. and Gholian, R.N. (1997). Effect of synthetic and natural coagulant on lignin removal from pulp and paper wastewater. Wat. Sci. Tech. 35: 286291

Hewitt, C.D., Savory, J., Wills, M.R. (1990). Aspects of Aluminum Toxicity. From Cline lab Med, Jun 10(2): 403-22.

Ho, Y.C., Norli, I., Norhashimah, M. (2008). Pectin as Bio-flocculants For Turbidity Reduction in Waste Water Treatment. International Conference on Environmental Research and Technology, ICERT.

Jenny, P. and Todd, P. (2008). Jar Testing. water Treatment primer, CE4124: Environmental Information Management, Civil Engineering Dept., Virginia Tech.

Katayon, S., Megat, M.J., Mohd, N. (2004). Effects of storage duration and temperature of Moringa oleifera stock solutions performance in coagulation. International Journal of Engineering and Technology, Vol. 1, No. 2, pp. $146-$ 151.

Kawamura, S. (1991). Effectiveness of natural polyelectrolyte's in water treatment. JAWWA.

Kerri, K.D. (2008). Water Treatment plant Operation. California State University: Sacramento.

Lee, S.H., Lee, S.O., Jang, K.L., Lee, T.H. (1995). Microbial flocculants from arcuadendron SP-49. Biotechnol. Lett. 17(1), 95-100.

Lee, C.C., Shun, L.D. (2007). Hand Book of Environmental Engineering Calculations. Mc Graw-Hill companies.
Mahvi, A.H. and Razavi, M. (2005). Application of Polyelectrolyte in Turbidity Removal from Surface Water. American J. Applied Sci., 2 (1): 397-399.

Metcalf, and Eddy, (1982). Inc. Wastewater Engineering. McGraw Hill, New York, USA.

Nasser, S. (1994). Coagulant and coagulation processes: basic methods in water treatment industry. Seminar Proceedings of Coagulant in Water Industry, Ahvaz, Iran.

Pricilla, C.F., Kamila, A.P., Angela, M.M.T. and Susana, I.S.M. (2008). Aluminum risk factor for Alzheimer's disease.

Qilin, L. and Laura, K. (2005). Assessing the effectiveness and environmental impacts of using natural flocculants to manage turbidity. Department of Civil, Construction and Environmental Engineering Oregon State University Corvallis.

Susan, J.D. (2008). Aluminum Poisoning.

The lancet, Jan.14, (1989). "Geographical relation between Alzheimer's disease and aluminum in drinking water" http://trufax.org/general/aluminum.html.

The silent enemy, Aluminum poisoning, (2008). http://www.squidoo.com/aluminumpois oning

Virginie, R., Daniel, C., Helene, J.G., Daniel, C., Catherine, H. and Jean, F.D. (2008). Aluminum And Silica in Drinking Water and Risk of Alzheimer's Disease or Cognitive Decline. Findings from 15 year follow up of the PAQUID cohort.

Virginie, R., Daniel, C., Helene, J.G. and Jean, F.D. (1999). Relation between Aluminum Concentrations in drinking Water and Alzheimer's disease. An 8year follow up study. 


\title{
تأثير وقت الترسيب على تقليل جرعة المادة المخثرة المستخدمة في مشاريع معالجة المياه
}

\author{
صفاء ناصر حسن \\ عضو هيئة تدريسية في قسم هندسة البيئة / كلية الهندسة / الجامعة المستتصرية / باب المعظم / ص.ب. • 1 أ / بغداد / العراق
}

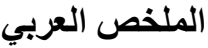

العكورة هي إحدى المشاكل الرئيسية في مشاريع معالجة المياه. التخلص من العكورة يتم عن طريق إضافة مادة مخثرة إلى الماء

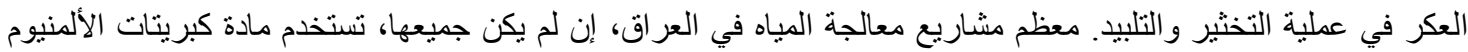

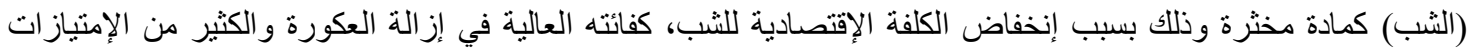

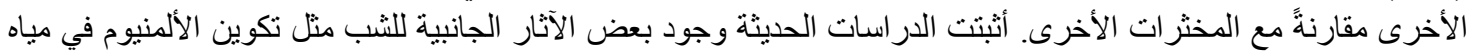

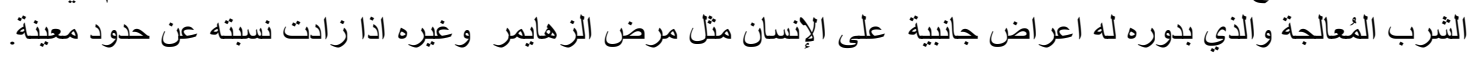

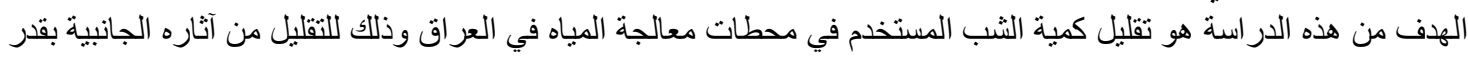

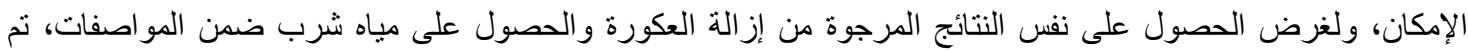

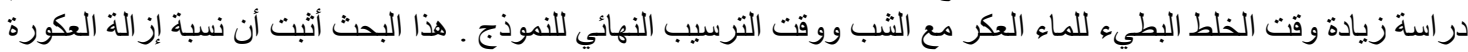

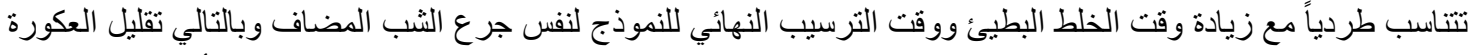

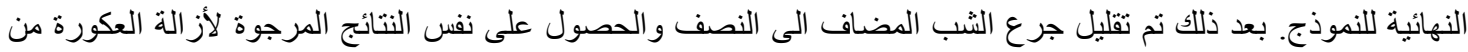

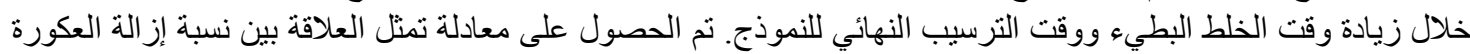

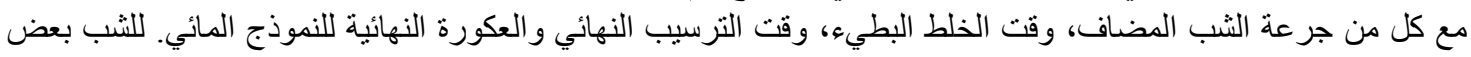

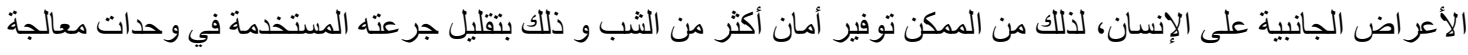

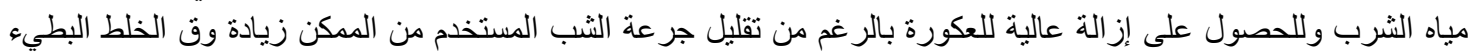

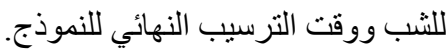

